\title{
Influence of Epidermal Growth Factor with Cysteamine on in -Vitro Buffalo Embryo Development
}

\author{
Al-Shimaa A.H. El-Naby ${ }^{*}$ Karima Gh. M. Mahmoud ${ }^{* *}$, \\ T.H. Scholkamy ${ }^{* * *}$, Y.F. Ahmed ${ }^{* *}$, G.A.M. Sosa* and \\ M.E.A. Abouel-Roos \\ *Department of Theriogenology, Faculty of Veterinary Medicine, \\ Benha University, Benha ${ }^{* *}$ Department of Animal Reproduction \\ and A.I., National Research Centre, and ${ }^{* * *}$ Artificial Insemination \\ and Embryo Transfer Dept., Animal Reproduction Research \\ Institute, Cairo, Egypt.
}

\begin{abstract}
7 OR IMPROVING embryo development in buffalo, two experiments were conducted. The first one was carried out to evaluate the different concentrations $(0,5,25,50 \mathrm{ng} / \mathrm{ml})$ of epidermal growth factors (EGF) on developmental competence of buffalo oocytes. The selected oocytes were cultured in the four concentrations of EGF. The embryo cleavage rate was significantly higher in oocytes exposed to $5,25,50 \mathrm{ng} / \mathrm{ml}$ EGF than control. There were no significant difference in four groups $(0,5,25,50 \mathrm{ng} / \mathrm{ml}$ EGF) in the rate of morula. But, better cleavage and blastocyst rates were observed at $5 \mathrm{ng} / \mathrm{ml}$ EGF. In the second experiment, the additive effect of $5 \mathrm{ng} / \mathrm{ml}$ EGF with $50 \mu \mathrm{M}$ cysteamine on maturation and embryo development was studied. Oocytes were collected, matured and cultured in three groups. In the first group, media supplemented with $5 \mathrm{ng} / \mathrm{ml} \mathrm{EGF}+50 \mu \mathrm{M}$ cysteamine combination. In the second group, media supplemented with EGF. The third group was supplemented with cysteamine. There was a significant increase in cleavage rate in combination group than EGF $(P<0.05)$ and cysteamine $(P<0.01)$ groups. But there was no significant difference in cleavage rate between EGF and cysteamine. The morula percentage was nearly similar in the three groups. But blastocyst rate was significantly $(P<0.05)$ higher in combination group than cysteamine. Thus better cleavage and blastocyst rate were observed at combination group. It is concluded that, the addition of $5 \mathrm{ng} / \mathrm{ml} \mathrm{EGF}$ in buffalo oocytes during in vitro culture was the best concentration for embryo developmental competence. Higher cleavage and blastocyst rate were achieved by combination of epidermal growth factor and antioxidant.
\end{abstract}

Keywords: Buffalo oocytes, EGF, Cysteamine, Embryo development, Culture media.

There were many growth factors as insulin growth factors (IGFs), epidermal growth factor (EGF), transforming growth factor $\alpha, \beta$ and activin acted as 
regulators for modulate follicular development, granulosa cell proliferation, decreased apoptosis and promoted follicular antrum formation (Mtango et al., 2002 and Purohitc et al., 2005). The EGF was first discovered as one from EGF family proteins (Dreux et al., 2006). It had a mitogenic effect in a variety of species such as cattle (Lorenzo et al.,1994, Kobayashi et al., 1994 and Reiger et al., 1995), pigs (Reed et al., 1993, Ding and Foxcroft, 1994), rodents (Das et al.,1992 and Demeestere et al., 2005), buffalo (Chauhan et al., 1999 and Kumar \& Purohit, 2004), sheep (Grazul-Bilska et al., 2003, Shabankareh and Zandi, 2010), dog (Bolamba et al., 2006), rabbit (Lorenzo et al.,1996), cat (Merlo et al., 2005) and humans (Das et al.,1991 and Gomez et al.,1993).

EGF had a positive effect during in vitro maturation by stimulating the ovarian granulosa cells proliferation (May et al.,1987), growth of preantral follicles (Gutierrez et al.,2000), promoting oocyte maturation (Sanbuissho et al.,1991), germinal vesicle breakdown, polar body formation (Das et al., 1991) and cleavage of oocytes (Coskun et al.,1991). EGF stimulated DNA synthesis in cumulus cells (Lonergan et al., 1996 and Khamsi \& Armstrong, 1997), induced proteoglycan synthesis (Das et al., 1991), production of tissue plasminogen activator and urokinase plasminogen activator by cumulus cells which stimulated oocyte maturation (Park et al., 1999).

Cysteamine was a low molecular weight thiol compound that might reduce cysteine to cystine which enhanced oocyte glutathione synthesis (Issels et al., 1988) which protected the cell from oxidative damage (Wang \& Ballatori, 1998, Hammond et al., 2001 and Deleuze \& Goudet, 2012), improved the formation of male pronucleus, protein, DNA synthesis and reduction of disulphides (Kim et al., 2004). In buffalo, cysteamine supplementation was reported to improve nuclear maturation rates (Singhal et al., 2009) by increasing GSH synthesis (Gasparrini et al., 2003) and improve male pronucleus formation (Anandi et al., 2008). Furthermore, cysteamine increased cleavage rates following IVM (Singhal et al., 2009) and subsequent embryonic development in vitro (Ocampo and Ocampo, 2015).

Based on the above knowledge, this work aimed to improve buffalo embryo development by using growth factor as epidermal growth factor and prevent oxidative stress by cysteamine addition.

\section{Material and Methods}

\section{Experimental Designs}

Experiment 1: Evaluation the effect of different concentrations of EGF on developmental competence of buffalo oocytes.

EGF was added to maturation and culture media at different concentrations $(0,5,25,50 \mathrm{ng} / \mathrm{ml})$, oocytes incubated in $\mathrm{CO}_{2}$ incubator at $38^{\circ} \mathrm{C}$ for $5-7$ day. The optimum concentration which achieved higher cleavage, morula and blastocyst rate was recorded.

Egypt. J. Vet. Sci. Vol. 47, No. 1 (2016) 
Experiment 2: The effect of combination of EGF and cysteamine on developmental competence of buffalo oocytes.

Three groups of buffalo oocytes matured and cultured in $\mathrm{CO}_{2}$ incubator at $38^{\circ} \mathrm{C}$ for 5-7 days. Oocytes was cultured in media supplemented with both 5 $\mathrm{ng} / \mathrm{ml} \mathrm{EGF}+50 \mu \mathrm{M}$ cysteamine (Group I), 5ng/ml EGF (Group II). $50 \mu \mathrm{M}$ cysteamine (Group III). Cleavage, morula and blastocyst rate were recorded.

\section{Chemicals}

Chemicals for in vitro maturation as fetal calf serum and tissue culture medium (TCM-199) were obtained from Gibico (Grand Island, New York, USA). Cysteamine (M 6500), epidermal growth factor (E1257) and chemicals for in vitro fertilization were obtained from Sigma Chemical Company.

\section{Oocyte recovery}

Ovaries were collected from Cairo abattoir within $2 \mathrm{~h}$ of slaughter and transported to the laboratory in saline $(0.9 \% \mathrm{NaCl})$ containing antibiotics (100 $\mu \mathrm{g} / \mathrm{ml}$ streptomycin sulfate and $100 \mathrm{IU} / \mathrm{ml}$ penicillin) maintained at $30^{\circ} \mathrm{C}$. After washing the ovaries in phosphate- buffered saline (PBS), oocytes were aspirated from 2 to $5 \mathrm{~mm}$ follicles with a 20-gauge needle containing PBS with $0.3 \%$ bovine serum albumin (BSA) and antibiotics $(100 \mu \mathrm{g} / \mathrm{ml}$ streptomycin sulfate and $100 \mathrm{IU} / \mathrm{ml}$ penicillin).

\section{In vitro oocyte maturation}

The maturation was carried out as previously described (Mahmoud, 2001). The selected oocytes were cultured in medium consisted of TCM-199, 10\% calf serum, and $50 \mu \mathrm{g} / \mathrm{ml}$ gentamycin. The droplets were covered with mineral oil and were pre-incubated for a minimum $2 \mathrm{~h}$ at $38.5{ }^{\circ} \mathrm{C} 5 \% \mathrm{CO}_{2}$ in air with $95 \%$ humidity. The oocytes were added to droplets and incubated for $24 \mathrm{hr}$.

\section{In vitro fertilization and culture}

Spermatozoa were treated as described previously by Niwa and Ohgoda (1988). Briefly, two straws of frozen buffalo semen were thawed in a water bath at $35-37^{\circ} \mathrm{C}$ for $1 \mathrm{~min}$. The spermatozoa were washed by centrifugation $(800 \times \mathrm{g}$ for $10 \mathrm{~min}$ ) in BO medium (Brackett and Oliphant, 1975) without BSA containing $10 \mu \mathrm{g} / \mathrm{ml}$ heparin and $2.5 \mathrm{mM}$ caffeine. The pellets were diluted with BO medium containing $20 \mathrm{mg} / \mathrm{ml}$ bovine serum albumin to adjust the concentration of spermatozoa to $12.5 \times 10^{6} \mathrm{sperm} / \mathrm{ml}$. Matured oocytes were washed in BO medium containing $10 \mathrm{mg} / \mathrm{ml} \mathrm{BSA}$ and were introduced into 100 $\mu 1$ droplets of sperm suspension under paraffin oil, the spermatozoa and oocytes were co-cultured in the same culture conditions $\left(5 \% \mathrm{CO}_{2}, 38.5{ }^{\circ} \mathrm{C}, 95 \%\right.$ humidity) for $5 \mathrm{~h}$ under. After that, the oocytes were washed in TCM-199 to remove attached spermatozoa. Groups of 10-20 oocytes were replaced with previously prepared co-culture $100 \mu \mathrm{l}$ droplet consisting of TCM-199+10\% serum. Cleavage was recorded after $72 \mathrm{hr}$ of culture (day $0=$ day of insemination) 
and the embryos developing to the morula and blastocyst stages were assessed at days 5 and 7 , respectively.

\section{Statistical analysis}

Our results were tabulated to indicate the mean values of the studied parameters and their standard errors. Data were analyzed by ANOVA using SPSS version 18.0, statistical software. Comparison of means was performed by Duncan's Multiple Range Test. Differences were considered to be significant at $P<0.05$ level.

\section{In the first experiment}

\section{Results}

Oocytes were matured and cultured in different concentrations of EGF and fertilization output was evaluated. Data in Table 1 indicated that the cleavage rate was significantly $(P<0.05)$ higher in oocytes treated with $5,25,50 \mathrm{ng} / \mathrm{ml}$ EGF than control. While the embryo cleavage rate was not significantly differ between $25 \mathrm{ng} / \mathrm{ml}$ and $50 \mathrm{ng} / \mathrm{ml}$ of EGF. The better cleavage rate was observed at concentration $5 \mathrm{ng} / \mathrm{ml} \mathrm{EGF}$.

The mean percentage of morula after treated with different concentrations $(0,5,25,50 \mathrm{ng} / \mathrm{ml})$ of EGF was illustrated in Table 1 . There was no significant difference in oocytes treated by $5,25,50 \mathrm{ng} / \mathrm{ml}$ EGF and control group in the percent of morula. The morula percent was $45.94,46.38,48.0$ and 44.9 for control, 5, 25, $50 \mathrm{ng} / \mathrm{ml} \mathrm{EGF,} \mathrm{respectively.}$

The blastocyst rate after treated with different concentrations $(0,5,25,50$ $\mathrm{ng} / \mathrm{ml}$ ) of EGF was recorded in Table 1 . The blastocyst rate was significantly increased $(P<0.05)$ in $5 \mathrm{ng} / \mathrm{ml}$ EGF than control. At the same time, there were no significant differences between control and other concentrations of 25 and 50 $\mathrm{ng} / \mathrm{ml}$. Better blastocyst rate was observed at $5 \mathrm{ng} / \mathrm{ml}$.

TABLE 1. The effect of different EGF concentrations on embryo developmental rate of buffalo oocytes (Mean \pm S.E).

\begin{tabular}{|l|c|c|c|c|}
\hline $\begin{array}{l}\text { Epidermal } \\
\text { growth factor } \\
\text { concentrations }\end{array}$ & $\begin{array}{c}\text { No. } \\
\text { Inseminated } \\
\text { oocytes }\end{array}$ & $\begin{array}{c}\text { Cleavage } \\
\text { No. }(\%)\end{array}$ & $\begin{array}{c}\text { Morula } \\
\text { No. }(\%)^{*}\end{array}$ & $\begin{array}{c}\text { Blastocyst } \\
\text { No. }(\%)^{*}\end{array}$ \\
\hline Control (0) & 84 & $45(54.31 \pm 2.6)^{\mathrm{b}}$ & $38(45.94 \pm 2.4)^{\mathrm{a}}$ & $7(8.37 \pm 0.4)^{\mathrm{b}}$ \\
\hline $5 \mathrm{ng} / \mathrm{ml}$ EGF & 87 & $53(62.41 \pm 2.7)^{\mathrm{a}}$ & $40(46.38 \pm 3.1)^{\mathrm{a}}$ & $11(12.52 \pm 1.1)^{\mathrm{a}}$ \\
\hline $25 \mathrm{ng} / \mathrm{ml} \mathrm{EGF}$ & 97 & $58(61.15 \pm 1.1)^{\mathrm{ab}}$ & $47(48.00 \pm 2.0)^{\mathrm{a}}$ & $12(11.82 \pm 1.0)^{\mathrm{ab}}$ \\
\hline $50 \mathrm{ng} / \mathrm{ml} \mathrm{EGF}$ & 98 & $55(56.77 \pm 1.3)^{\mathrm{ab}}$ & $43(44.9 \pm 1.8)^{\mathrm{a}}$ & $9(9.89 \pm 1.6)^{\mathrm{ab}}$ \\
\hline
\end{tabular}

Percent from total inseminated oocytes

No.= number

a, b Values within same column without common superscripts differ $(p<0.05)$.

Egypt. J. Vet. Sci. Vol. 47, No. 1 (2016) 


\section{In the second experiment}

The combination effect between epidermal growth factor and cysteamine on developmental competence of buffalo oocytes was evaluated.

Data regarding the combination effect between $5 \mathrm{ng} / \mathrm{ml}$ of EGF and $50 \mu \mathrm{M}$ cysteamine on cleavage, morula and blastocyst rates was illustrated in Table 2. There was a significant increase in cleavage rate in combination group than EGF $(P<0.05)$ and cysteamine $(P<0.01)$ groups. But, there were no significant differences in cleavage rate between EGF and cysteamine treated groups.

The morula percentages were $50.43 \%, 46.73 \%, 42.21 \%$ for combination, EGF and cysteamine groups, respectively. There were no significant difference between combination and EGF group in morula rate. Morula percentage was nearly similar in EGF and cysteamine groups. While, the morula percentage was significantly $(P<0.05)$ higher in combination than cysteamine group.

The mean proportion of blastocyst rates were illustrated in Table 2. The blastocyst rate was significantly $(P<0.05)$ higher in combination group than cysteamine. But, there was non-significant difference between combination group and EGF group. Blastocyst rate was nearly similar in EGF and cysteamine groups. Thus, better blastocyst rate was observed at combination of EGF and cysteamine group.

TABLE 2. The effect of EGF and cysteamine combination on developmental competence of buffalo oocytes (Mean $\pm \mathrm{S}$. E).

\begin{tabular}{|l|c|c|c|c|}
\hline \multicolumn{1}{|c|}{$\begin{array}{c}\text { Treatment } \\
\text { groups }\end{array}$} & $\begin{array}{c}\text { Total No. of } \\
\text { inseminated } \\
\text { oocytes }\end{array}$ & $\begin{array}{c}\text { Cleavage } \\
\text { No. }(\%)\end{array}$ & $\begin{array}{c}\text { Morula } \\
\text { No. }(\%)^{*}\end{array}$ & $\begin{array}{c}\text { Blastocyst } \\
\text { No. }(\%)^{*}\end{array}$ \\
\hline $\begin{array}{l}\text { EGF }+ \\
\text { Cysteamine }\end{array}$ & 88 & $64(72.88 \pm 1.1)^{\mathrm{a}}$ & $43(50.43 \pm 2.5)^{\mathrm{a}}$ & $15(17.70 \pm 1.9)^{\mathrm{a}}$ \\
\hline EGF & 131 & $83(64.88 \pm 2.8)^{\mathrm{b}}$ & $60(46.73 \pm 1.6)^{\mathrm{ab}}$ & $16(13.07 \pm 1.5)^{\mathrm{ab}}$ \\
\hline Cysteamine & 98 & $60(60.51 \pm 2.5)^{\mathrm{b}}$ & $42(42.21 \pm 2.6)^{\mathrm{b}}$ & $12(12.32 \pm 0.5)^{\mathrm{b}}$ \\
\hline
\end{tabular}

*Percent from total inseminated oocytes

No.= number

${ }^{\mathrm{a}, \mathrm{b}}$ Values within the same column differ significantly $(P<0.05-P<0.01)$.

\section{Discussion}

The first aim in the present study analyzed the effect of different concentrations of EGF on buffalo embryo developmental rate. In our result, the embryo cleavage rate was significantly higher in oocytes treated with 5, 25 and $50 \mathrm{ng} / \mathrm{ml}$ of EGF concentrations than control. While, there were no significant difference in four groups $(0,5,25,50 \mathrm{ng} / \mathrm{ml} \mathrm{EGF})$ in the rate of morula. But, at $5 \mathrm{ng} / \mathrm{ml}$ EGF, the better blastocyst rate was observed. So, the highest cleavage and blastocyst rate were achieved at concentration $5 \mathrm{ng} / \mathrm{ml} \mathrm{EGF}$. 
Our result was in accordance with Sirisathien et al. (2003) and Thongkittidilok et al. (2015) who observed that oocyte competence and blastocyst developmental rate were improved at concentration $5 \mathrm{ng} / \mathrm{ml}$ EGF compared with un supplemented group in bovine and cat, respectively. It was suggested that EGF enhanced oocytes developmental competence and blastocyst formation in single-embryo culture system, but did not affect embryo development in cultured groups, this discrepancy might be due to a speciesspecific response to EGF (Thongkittidilok et al., 2015).

In contrast to our study, many reports stated that oocytes maturation and embryo development rate were increased at concentration $10 \mathrm{ng} / \mathrm{ml} \mathrm{EGF}$ in several species as bovine (Lonergan et al., 1996 and Mtango et al., 2003), porcine (Abeydeera et al., 1998, Sirotkin et al., 2000 and Mao et al., 2004) and buffalo (Kumar \& Purohit, 2004 and Purohit et al., 2005). While, Singhal et al. (2009), Kandil et al. (2013) and Sadeesh et al. (2014) mentioned that the optimum concentration of EGF was $20 \mathrm{ng} / \mathrm{ml}$ for buffalo embryo development in vitro.

It was suggested that at higher concentrations (40 $\mathrm{ng} / \mathrm{ml})$, blastocyst development was reduced (Carpenter \& Cohen, 1976 and Sirotkin et al., 2000) due to a phenomenon termed growth factor-induced receptor down regulation. Thus the presence of high concentration of EGF caused a significant down regulation or acceleration of EGF receptors degradation (Beguinot et al., 1984). While in sheep, $\mathrm{Ni}$ et al. (2015) proved that in vitro embryo developmental rate was significantly higher at concentration $50 \mathrm{ng} / \mathrm{ml}$ EGF. But, the suitable concentration for mouse embryo development was $1 \mathrm{ng} / \mathrm{ml} \mathrm{EGF}$ (Merriman et al., 1998).

When TCM-199 was supplemented with optimum concentration of EGF during IVM, cumulus cells expansion were stimulated, percentage of nuclear matured oocytes were increased as well as the proportion of embryos attaining blastocyst stage were increased (Buyalos and Cai, 1994, Lonergan et al., 1996). EGF considered as local regulators for cell proliferation and differentiation (Teruel et al., 2000), might be one of the signaling factors for resumption of meiosis of oocytes (Coskun et al., 1991), promoted follicular antrum formation, and suppressed granulosa cell apoptosis (Mao et al., 2002). Also, EGF stimulated DNA synthesis in cumulus cells (Khamsi and Armstrong, 1997) and stimulated the pattern of proteins neosynthesis (Lonergan et al., 1996). Moreover, Lee and Fukui (1995) observed that the stimulatory effect of EGF existed in post-fertilization bovine embryonic development especially at morulae/early blastocysts than early IVM condition. When bovine blastocysts were cultured, vitrified in media with EGF, higher developmental capacity were observed (Mtango et al., 2003).

On the other hand, some studies stated that the growth factors as EGF had no positive effect on mouse (Wood \& Kaye, 1989 and Colver et al., 1991) and bovine (Yang et al.,1993 and Keefer et al., 1994) embryonic developmental rate in vitro.

Egypt. J. Vet. Sci. Vol. 47, No. 1 (2016) 
In the present work, the additive effect of $5 \mathrm{ng} / \mathrm{ml}$ EGF and $50 \mu \mathrm{M}$ cystamine on maturation and embryo development were studied. There was a significant increase in cleavage and blastocyst rates in combination group than EGF and cysteamine groups. But, the morula percentage was nearly similar between three groups.

EGF along with antioxidants increased maturation rate which might be due to assessment of oocyte maturation on the basis of cumulus expansion, not by nuclear maturation (Lorenzo et al., 1994 and Singhal et al., 2009). It was suggested that cysteamine was a better antioxidant than $\beta$-mercaptoethanol for in vitro embryo production (De Matos et al., 2002). Addition of cysteamine enhanced the glutathione synthesis in maturation medium (De Matos and Furnus, 2000) to improve oocyte maturation by protecting oocytes from oxidative stress (Gasparrini et al., 2003). In the culture medium, cysteamine improved blastocyst production rate and enhanced embryo quality in various species as bovine (Lojkic et al., 2012) and buffalo (Ocampo and Ocampo, 2015). Moreover, it improved transformation efficiency of sperm head nucleus into male pronucleus during fertilization.

In opposite to our result, Singhal et al. (2009) mentioned that using $20 \mathrm{ng} / \mathrm{ml}$ EGF+ $50 \mu \mathrm{M}$ cysteamine had no positive effect on oocyte maturation and buffalo embryo development. While, oocyte maturation and embryo development were improved by using $20 \mathrm{ng} / \mathrm{ml}$ EGF $+100 \mu \mathrm{M} \beta$-mercaptoethanol. Oyamada and Fukui (2004) reported that the combination group had no positive effect on nuclear maturation, but improved cleavage rate of bovine oocytes. The difference between previous studies and our results may be attributed to the concentration of growth factor.

\section{Conclusion}

The addition of $5 \mathrm{ng} / \mathrm{ml}$ EGF during in vitro culture was the best concentration for embryo developmental competence. Higher cleavage and blastocyst rate were achieved by combination of epidermal growth factor and cysteamine in buffalo.

\section{Declaration of interest}

The authors declare that there is no conflict of interest.

\section{References}

Abeydeera, L.R., Wang, W.H., Cantly, T.C., Prather, R.S. and Day, B.N. (1998) Presence of $\beta$-mercaptoethanol can increase the glutathione content of pig oocytes matured in vitro and the rate of blastocyst development after in vitro fertilization. Theriogenol., 50, 747-756. 
Anandi, T., Kumar, D., Chauhan, M.S., Manik, R.S. and Palta, P. (2008) Cysteamine supplementation of in vitro maturation medium, in vitro culture medium or both media promotes in vitro development of buffalo (Bubalusbubalis) embryos. Reprod. Fertil. Dev., 20, 253-257.

Beguinot, L.,Liall, R.M., Willingham, M.C. and Pastan, I. (1984) Down-regulation of the epidermal growth factor receptor in $\mathrm{KB}$ cells is due to receptor internalization and subsequent degradation in lysosomes. Proc. Natl. Acad. Sci., 81, 2384-2388.

Bolamba, D., Russ, K.D., Harper, S.A., Sandler, J.L. and Durrant, B.S. (2006) Effects of epidermal growth factor and hormones on granulosa expansion and nuclear maturation of dog oocytes in vitro. Theriogenology, 65, 1037-1047.

Brackett, B.G. and Oliphant, G. (1975) Capacitation of rabbit spermatozoa in vitro. Biol. of Reprod., 12, 260- 274.

Buyalos, R.P. and Cai, X. (1994) Pre-implantation embryo development enhanced by epidermal growth factor. J. Assist.Reprod.Genet., 11, 33-37.

Carpenter, G. and Cohen, S. (1976) 125I-Labeled human epidermal growth factor: Binding, internalization, and degradation in human fibroblasts. J. Cell. Biol., 71, 159171.

Chauhan, M.S.,Singla, S.K.,Palta, P.,Manik, R.S. and Madan, M.L. (1999) Effect of EGF on cumulus expansion, mitotic maturation and development of buffalo oocytes in vitro. Vet. Rec., 144, 266-270.

Colver, R.M., Howe, A.M., Mcdonough, P.G. and Boldt, J. (1991) Influence of growth factors in defined culture medium on in vitro development of mouse embryo. Fertil.Steril., 55, 194-199.

Coskun, S., Sonbuissho, A., Lin, Y.C. and Rikihisa, Y. (1991) Fertilization and subsequent developmental ability of bovine oocytes matured in medium containing epidermal growth factor. Theriogenology, 36, 485-494.

Das, K., Phipps, W.R., Hensleigh, H.C. and Tagatz, G.E. (1992) Epidermal growth factor in human follicular fluid stimulates mouse oocyte maturation in vitro. Fertil. Steril., 57, 895-901.

Deleuze, S. and Goudet, G. (2012) Cysteamine Supplementation of In vitro Maturation Media: A Review. Reprod. Dom. Anim., 45, e476-e482.

De Matos, D.G. and Furnus, C.C. (2000) The importance of having high glutathione (GSH) level after bovine in vitro maturation on embryo development effect of betamercaptoethanol, cysteine and cystine. Theriogenol., 53, 761-771.

De Matos, D.G., Gasparrini, B., Pasqualini, S.R. and Thompson, J.G., (2002) Effect of glutathione synthesis stimulation during in vitro maturation of ovine oocytes on embryo development and intracellular peroxide content. Theriogenol., 57, 1443-1451. 
Demeestere, I., Centner, J., Gervy, C., Englert, Y. and Delbaere, A. (2005) Impact of various endocrine and paracrine factors on in vitro culture of preantral follicles in rodents. Reprod., 130, 147-156.

Ding, J. and Foxcroft, G.R. (1994) Epidermal growth factor enhances oocyte maturation in pigs. Mol. Reprod. Dev., 39, 30-40.

Dreux, A.C., Lamb, D.J., Modjtahedi, H. and Ferns, G.A. (2006) The epidermal growth factor receptors and their family of ligands, their putative role in a thermogenesis. Atherosclerosis, 186 (1), 38-53.

Gasparrini, B.,Sayoud, H.,Neglia, G., Matos, D.G., Donnay, I. and Zicarelli, L. (2003) Glutathione synthesis during in vitro maturation of buffalo (Bubalus bubalis) oocytes: Effects of cysteamine on embryo development. Theriogenol., 60, 943-952.

Gomez, E.,Tarin, J.J. and Pellicer, A. (1993) Oocyte maturation in humans: The role of gonadotropins and growth factors. Fertil. Steril., 60, 40-46.

Grazul-Bilska, A.T., Choi, J.T., Bilski, J.J., Weigl, R.M., Kirsch, J.D., Kraft, K.C., Reynolds, L.P. and Redmer, D.A. (2003) Effects of epidermal growth factor on early embryonic development after in vitro fertilization of oocytes collected from ewes treated with follicle stimulating hormone. Theriogenology, 59, 1449-1457.

Gutierrez, C.G., Ralph, J.H., Telfer, E.E., Wilmut, I. and Webb, R. (2000) Growth and antrum formation of bovine preantral follicles in long-term culture in vitro. Biol. Reprod., 62, 1322-1328.

Hammond, C.L., Lee, T.K. and Ballatori, N. (2001) Novel roles for glutathione in gene expression, cell death, and membrane transport of organic solutes. J. Hepatol., 34, 946-954.

Issels, R.D., Nagele, A., Eckert, K.G. and Wilmanns, W. (1988) Promotion of cysteine uptake and its utilization for glutathione biosynthesis induced by cysteamine and $\mathrm{N}$ acetil-cysteine. Biochem.Pharmacol., 37, 881-888.

Kandil, O.M., Abdoon, A.S.S., Kacheva, C.H.D. and Georgiev, B. (2013) Effect of in vitro culture media on embryo developmental competence and vitrification methods in blastocyst viability in buffalo. Global Vet., 11 (5), 622-629.

Keefer, C.L., Stice, S.L., Paprocki, A.M. and Golueke, P., (1994) In vitro culture of bovine IVM-IVF embryos: Cooperative interaction among embryo and the role of growth factors. Theriogenol., 41, 1323-1331.

Khamsi, F. and Armstrong, D.T. (1997) Interactions between follicle stimulating hormone and growth factors in regulation of deoxyribonucleic acid synthesis in bovine granulosa cells. Biol. Reprod., 57, 684-688.

Kim, M.K., Fibrianto, H.Y., Oh, H.J., Jang, G., Kim, H.J., Lee, K.S., Kang, S.K., Lee, B.C. and Hwang, W.S. (2004) Effect of $\beta$-mercaptoethanol or epidermal growth factor supplementation on in vitro maturation of canine oocytes collected from dogs with different stages of the estrus cycle. J. Vet. Sci., 5, 253-258. 
Kobayashi, L., Yamashita, S. and Hoshi, H. (1994) Influence of epidermal growth factors and transforming growth factor 1 on in vitro maturation of cumulus cell enclosed bovine oocytes in a defined medium. J. Reprod. Fertil., 100, 439-446.

Kumar, D. and Purohit, G.N. (2004) Effect of epidermal and insulin-like growth factor1 on cumulus expansion, nuclear maturation and fertilization of buffalo cumulus oocyte complexes in simple serum free media DMEM and Ham's F-10. Vet. Arhiv., 74, 13-25.

Lee, E.S. and Fukui, Y. (1995) Effect of various growth factors in a defined culture medium on in vitro development of bovine embryos matured and fertilized in vitro. Theriogenol., 44, 71-83.

Lojkic, M., Getz, I., Samardzija, M., Matkovic, M.,Bacic, G., Karadjole, T., Macesic, N., Folnozic, I. and Spoljaric, B. (2012) Effect of cysteamine supplementation during in vitro culture of early stage bovine embryos on blastocyst rate and quality. Acta Vet. Brno., 81, 229-234.

Lonergan, P., Carolan, C., Van-Langendonckt, A., Donnay, I.,Khatir, H. and Mermillod, P. (1996) Role of epidermal growth factor in bovine oocyte maturation and preimplantation embryo development in vitro. Biol. Reprod., 54, 1420-1429.

Lorenzo, P.L., Illera, M.J., Illera, J.C. and Illera, M. (1994) Enhancement of cumulus expansion and nuclear maturation during bovine oocyte maturation in vitro by the addition of epidermal growth factors and insulin like growth factors. J. Reprod. Fertil., 101, 697-701.

Lorenzo, P.L., Rebollar, P.G., Illera, M.J., Illera, J.C. and Illera, M. (1996) Stimulatory effect of insulin-like growth factor I and epidermal growth factor on the maturation of rabbit oocytes in vitro, J. Reprod. Fertil., 107, 109-117.

Mao, J., Wu, G., Smith, M.F., McCauley, T.C., Cantley, T.C., Prather, R.S., Didion, B.A. and Day, B.N. (2002) Effects of culture medium, serum type, and various concentrations of follicle-stimulating hormone on porcine preantral follicular development and antrum formation in vitro. Biol. Reprod., 67, 1197-1203.

Mao, J., Smith, M.F., Rucker, E.B., Wu, G.M., McCauley, T.C., Cantley, T.C., Prather, R.S., Didion, B.A. and Day, B.N. (2004) Effect of epidermal growth factor and insulin-like growth factor I on porcine preantral follicular growth, antrum formation, and stimulation of granulosa cell proliferation and suppression of apoptosis in vitro. J. Anim. Sci., 82, 1967-1975.

May, J.V., Buck, P.A. and Schomberg, D.W. (1987) Epidermal growth factor enhances (125) iodo-follicle stimulating hormone binding by cultured porcine granulosa cells. Endocrinol., 120, 2413-2420.

Merriman, J.A. ,Whittingham, D.G. and Carroll, J. (1998) The effect of follicle stimulating hormone and epidermal growth factor on the developmental capacity of in-vitro matured mouse oocytes. Hum. Reprod., 13 (3), 690-695. 
Mtango, N.R., Varisanga, M.D. and Suzuki, T. (2002) Effect of growth hormone and growth factors on the improvement of culture conditions of in vitro produced bovine embryos. Pakistan J. Biol. Sci., 5 (5), 604-606.

Mtango, N.R., Varisanga, M.D., Dong, Y.J., Rajamahendran, R. and Suzuki, T. (2003) Growth factors and growth hormone enhance in vitro embryo production and post -thaw survival of vitrified bovine blastocyst. Theriogenol., 59, 1393-1402.

Ni, H., Sheng, X., Cui, X., Gu, M., Liu, Y., Qi, X., Xing, S. and Guo, Y. (2015) Epidermal growth factor-mediated mitogen-activated protein kinase3/1 pathway is conducive to in vitro maturation of sheep oocytes. PLOS ONE, 10 (3), 20418.

Niwa, K. and Ohgoda, O. (1988) Synergistic effect of caffeine and heparin on in-vitro fertilization of cattle oocytes matured in culture. Theriogenol., 30, 733-741.

Ocampo, L.C. and Ocampo, M.B. (2015) Improved developmental competence of swamp buffalo oocytes matured in the presence of cysteamine. J. Agric. Technol., 11 (1), 31-40.

Oyamada, T. and Fukui, Y. (2004) Oxygen tension and medium supplements for in vitro maturation of bovine oocytes cultured individually in a chemically defined medium. J. Reprod. Dev., 50, 107-117.

Park, K.W., Choi, S.H., Song, X.X., Funahashi, H. and Niwa, K. (1999) Production of plasminogen activators (PAS) in bovine cumulus oocyte complexes during maturation in vitro: Effect of epidermal growth factor on production of PAS in oocytes and cumulus. Cells Biol. Reprod., 61, 298-304.

Purohit, G.N., Brady, M.S. and Sharma, S.S. (2005) Influence of epidermal growth factor and insulin-like growth factor 1 on nuclear maturation and fertilization of buffalo cumulus oocyte complex in serum free media and their subsequent development in vitro. Anim. Reprod. Sci., 87, 229-239.

Mahmoud, K.Gh.M (2001) Cytogenetic studies on in-vitro fertilization in buffaloes. Ph.D. Thesis, (Theriogenol.) Fac. Vet. Med., Cairo university.

Merlo, B., Iacono, E., Zambelli, D.,Prati, F. and Belluzzi, S. (2005) Effect of EGF on in vitro maturation of domestic cat oocytes. Theriogenol., 63, 2032-2039.

Reed, M.L., Estrada, J.L., Illera, M.J. and Petters, R.M. (1993) Effect of epidermal growth factor, insulin like growth factor-I and dialyzed porcine follicular fluid on porcine oocyte maturation in vitro, J. Exp. Zool., 266, 74-78.

Reiger, D., Luciano, A.M., Modina, S., Pocar, P., Lauria, A. and Gandolfi, F. (1995) The effect of EGF and IGF-1 on metabolism and nuclear maturation of cattle oocytes. J. Reprod. Fertil., 15, Abstract p.73 .

Sadeesh, E.M., Shah, F., Balhara, A.K., Thirumaran, S.M.K., Yadav, S. and Yadav, P.S. (2014) Effect of growth factor and antioxidant on in vitro maturation of oocytes and cleavage rates of in vitro produced Indian buffalo(Bubalus bubalis) embryos. Veterinarski Archiv, 84 (5), 459-474. 
Sanbuissho, A.,Coskun, S. and Lin, Y.C. (1991) Stimulatory action of epidermal growth factor on in vitro bovine oocyte maturation. Ass. Reprod. Tech. Andr., 1, 143-153.

Shabankareh, H.K. and Zandi, M. (2010) Developmental potential of sheep oocytes cultured in different maturation media: effects of epidermal growth factor, insulin-like growth factor I, and cysteamine. Fertil. andsteril., 94, 335-340.

Singhal, S., Prasad, S., Singh, B., Prasad, J.K. and Gupta, H.P. (2009) Effect of including growth factors and antioxidants in maturation medium used for in vitro culture of buffalo oocytes recovered in vivo. Anim. Reprod. Sci., 113, 44-50.

Sirisathien, S., Hernandez-Fonseca, H.J. and Brackett, B.G. (2003) Influences of epidermal growth factor and insulin-like growth factor-I on bovine blastocyst development in vitro. Anim. Reprod. Sci.,77, 21-32.

Sirotkin, A.V., Dukesova, j., Makarevich, A.V., Kubek, A. and Bulla, J. (2000) Evidence that growth factors IGF-I, IGF-II and EGF can stimulate nuclear maturation of porcine oocytes via intracellular protein kinase A. Reprod. Nutr. Dev., 40, 559569.

Teruel, M., Smith, R. and Catalano, R. (2000) Growth factor: An embryo development. Biocell., 24, 107-122.

Thongkittidilok, C., Tharasanit, T., Songsasen, N., Sananmuang, T., Buarpung, S. and Techakumphu, M. (2015) Epidermal growth factor improves developmental competence and embryonic quality of singly cultured domestic cat embryos. $J$. Reprod. Dev., 61 (4), 269-276.

Wang, W. and Ballatori, N. (1998) Endogenous glutathione conjugates: Occurrence and biological functions. Pharmacol. Rev., 50 (3), 335-356.

Wood, S.A. and Kaye, P.L. (1989) Effects of epidermal growth factor on preimplantation mouse embryos. J. Reprod. Fertil., 85, 575-282.

Yang, B.K., Yang, X. and Foote, R.H. (1993) Effect of growth factors on morula and blastocyst development of in vitro matured and in vitro fertilized bovine oocytes. Theriogenol., 40 (3), 521-530. 


\section{تأثير عامل نمو الخلايا اللحائية (EGF) و السيستامين على تطور أجنة الجاموس معمليًا}

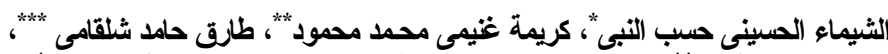

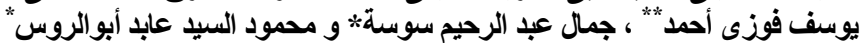

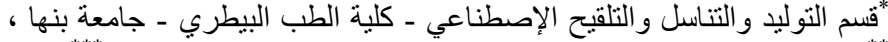

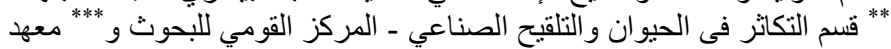
بحوث التناسليات بالهرم ـ مركز البحوث البحث الزراعي ـ اليركز ـ القاهرة ـ مصر.

أجريت تجربتين لدراسة تحسين تطور أجنة الجاموس معطلياً و تهدف التجربة

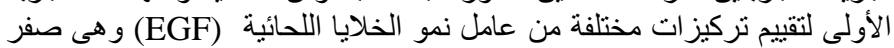

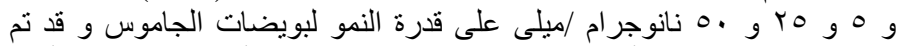

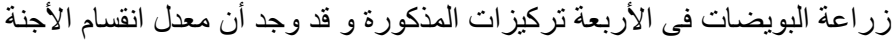

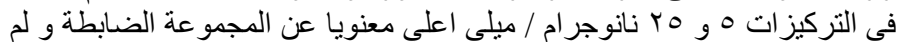

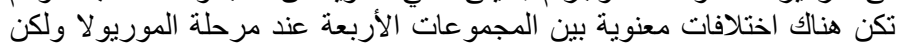

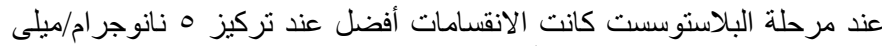

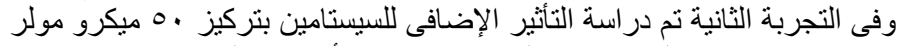

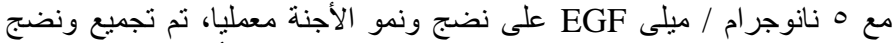

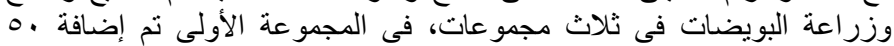

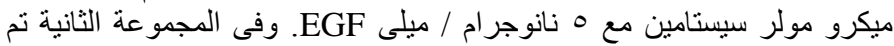

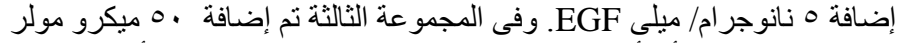

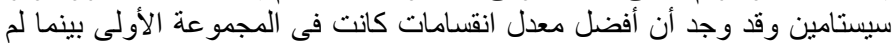

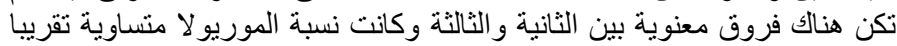

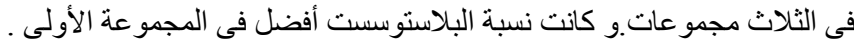

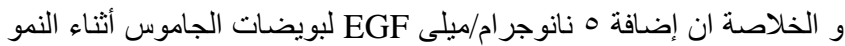

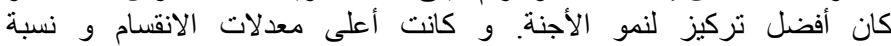

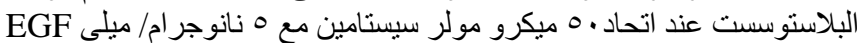

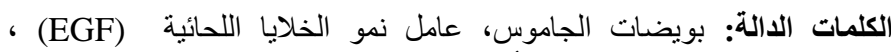

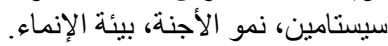

